\title{
An Agricultural Perspective for Combating Antibiotic Resistance: A Literature Review
}

Arian Karimi, BHSc Student [1], Cole Shulman, BHSc Student [2], Dennis Tchoudnovski, BHSc Student [1]*, Matthew Tobis, BSc Student [3]

All authors contributed equally.

[1] Bachelor of Health Sciences Program, McMaster University, Hamilton, Ontario, Canada [2] Department of Biochemistry and Biomedical Sciences, McMaster University, Hamilton, Ontario, Canada

[3] Department of Kinesiology, McMaster University, Hamilton, Ontario, Canada

*Corresponding Author: dennistch6345@gmail.com

\begin{abstract}
Introduction: The overuse of antibiotics has led to a surge of antibiotic resistant bacteria in recent decades. Animal agriculture has proven to be a significant contributor to this overuse. The investigation of potential alternatives to antibiotics in animal agriculture is thus warranted.

Methods: We conducted a literature review exploring four alternatives for antibiotic use in an animal agricultural setting: phytochemicals, antimicrobial peptides, probiotics, and bacteriophages.

Results: Four different types of antibiotic alternatives were evaluated. The first one is phytochemicals, a broad group consisting of five subtypes: alkaloids, carotenoids, polyphenols, terpenoids, and organosulfur compounds. Many of these display antibacterial properties such as interacting with the cytoplasmic membrane, immunomodulatory activities, inhibiting specific components of DNA replication, and even inactivating specific enzymes vital for the survival of bacteria. All these subtypes displayed various antibacterial properties in animal studies surrounding poultry and livestock. The second alternative is antimicrobial peptides, which have shown to be effective in treating conditions such as post-weaning stress and necrotic enteritis in various animals. The third alternative is probiotics, which have demonstrated both growth promotion and disease prevention properties. One study also concluded that probiotics provide financial benefits to farmers. The fourth antibiotic alternative is bacteriophages, a class of viruses that infect bacteria. Phages have shown disease prevention and growth promotion properties; they also can prevent the transmission of zoonotic diseases.

Discussion: Phytochemicals, antimicrobial peptides, probiotics, and bacteriophages all demonstrate the capability of acting as antibiotic alternatives. Each of these alternatives are unique with their own advantages and disadvantages; hence, the applicability is broad.

Conclusion: Four antibiotic alternatives (phytochemicals, antimicrobial peptides, probiotics, and bacteriophages) were researched for disease prevention and growth promotion properties, inherent functions of antibiotics. The applicability of such options in livestock and poultry is vast. Therefore, given more funding for research studies and policy changes, many of these options can be implemented if not already.
\end{abstract}

\section{Keywords}

antibiotic resistance; antibiotic alternatives; agriculture; phytochemicals; antimicrobial peptides; probiotics; bacteriophages; livestock; poultry

\section{Introduction}

The increasing prevalence of antibiotic resistant bacteria has called for the reduction of antibiotic use and the implementation of alternative agents to be explored. Due to the difficulties associated with treating resistant strains, a strong deterrent has been established against antibiotic usages in various practices [1].

Antibiotic use has been increasing significantly over the decade, with projections stating that China (the current largest consumer of antibiotics) will double its use in the next decade, with Brazil, Russia, India, and South Africa following suit [1]. With the increased necessity for higher agricultural yields, more antibiotics are being used, which in turn leads to more antibiotic resistant bacteria.

One major area of antibiotic use lies in animal agriculture for the purposes of increasing yield, maintaining health, and promoting growth [1-2]. A 2002 study on 
UNDERGRADUATE RESEARCH IN NATURAL AND CLINICAL SCIENCE AND TECHNOLOGY (URNCST) JOURNAL Read more URNCST Journal articles and submit your own today at: https://www.urncst.com

administrations of the antibiotic fluoroquinolone in poultry demonstrated a positive association with the increasing prevalence of resistant Campylobacter jejuni [3-4]. Subsequent analyses by the Food and Drug Administration (FDA) confirmed that agriculture had a role in this resistance development and banned further use of fluoroquinolones in poultry [3].

A considerable perpetrator to the creation of resistant bacteria is the "irrational use" of antibiotics [2,5]. This refers to the practice of overusing antibiotics without considerations for factors such as the geography, climate, and environmental surroundings, among other factors [2]. In fact, the subtherapeutic use of antibiotics for growth promotion poses a large threat as this practice has been associated with the emergence of resistant bacteria [3,6]. This widely practiced method involves using low concentrations of antibiotics that do not necessarily kill bacteria but instead improves feed efficiency, weight, and thus product yield [2-3,6]. However, the resulting resistant bacteria are selected for and make their way into humans via environmental contamination, food distribution, or direct contact with farm animals [7-8].

In bacteria, resistance genes can be formed spontaneously through random mutations, and can be transferred between bacteria through horizontal gene transfer (HGT) [9]. HGT has allowed for antibiotic resistance to spread from commensal non-pathogenic bacteria to pathogenic strains through conjugation, transduction, and natural transformation [10].

The main HGT process to transfer plasmids between bacteria is conjugation, which can be stimulated by antibiotics [11]. Jutkina et al. (2018) showed that several common antibiotics, including gentamicin and sulfamethoxazole, promoted the conjugal transfer of resistance genes at sub-therapeutic concentrations under the minimal inhibitory concentration (MIC) [12].

There is clearly an international incentive to reduce the irrational use of antibiotics and to consider alternative products to promote growth and prevent disease in an agricultural setting. Our literature review thus aims to answer the following question: what are some viable alternatives to using antibiotics in an animal agricultural setting to promote growth and prevent disease?

\section{Methods}

We conducted a literature review exploring four alternatives for antibiotic use within the animal agricultural setting: phytochemicals, antimicrobial peptides (AMPs), probiotics, and bacteriophages.

\section{Results}

With the increasing burden of antibiotic resistance, the search for efficacious alternative compounds is imperative and of high priority. Antibiotics display bacteriostatic and/or bactericidal effects, which antibiotic alternatives must attempt to mimic through growth prevention or disease prevention properties [2].

\section{Phytochemicals}

Phytochemicals are plant-derived compounds that have shown potential in both growth promotion and disease prevention [13]. These compounds can be categorized into 5 groups: alkaloids, carotenoids, polyphenols, terpenoids, and organosulfur compounds [14-15].

Alkaloids are organic nitrogenous bases that have been used for numerous medical interventions. These molecules are well known for their psychotropic effects as seen in morphine, caffeine, and cocaine. Many alkaloids have demonstrated antibacterial properties including the ability to partake in disruptive interactions with the cytoplasmic membrane of the bacteria, prevent formation of biofilms, and act as intercalating agents [15-17].

While carotenoids have not been widely used as antibacterial agents in agriculture, there is evidence of their potential to do so [15,18-19]. Carotenoids have been demonstrated to act as strong immunomodulatory compounds, which significantly improves an organism's ability to fight off bacteria [20]. In fact, an in-vivo study showed that curcumin, a carotenoid, was able to eradicate Helicobacter pylori in mice at an MIC (the lowest concentration preventing bacterial growth) of $5-50 \mu \mathrm{g} / \mathrm{mL}$, depending on the strain [21]. There is thus value in exploring its use in livestock and poultry [22]. However, a disadvantage of carotenoids is that they have been shown to potentially decrease the effects of certain antibiotics when used as an adjunctive [15,23].

Polyphenols can be classified into 2 major categories: flavonoids and non-flavonoids. Flavonoids are strong antibacterial agents due to their ability to disrupt DNA gyrase, inhibit nucleic acid synthesis, and prevent dNTP binding in both gram-positive and gram-negative bacteria [13,15,17,24]. Additional effects include increased permeability of the cell wall and cytoplasmic membrane as well as the ability to disrupt the functions of adhesins [17].

Terpenoids, such as carvacrol, have also shown strong potential to be antibacterial alternatives [14,25-26]. Like many terpenoids, carvacrol affects both gram-positive and gram-negative bacteria [14-15,25-26]. By inserting itself into the membrane of bacteria and dissolving the phospholipid bilayer, carvacrol causes disruptions in the ion gradient, instigating both bacteriostatic and bactericidal effects [14-15,27]. Additionally, many terpenes have demonstrated the ability to cause disruptions in biofilm formation, thus preventing bacterial growth [14-15].

Organosulfur compounds are another important group of phytochemicals. Hydrolysis of these compounds yields active antibacterial agents such as isothiocyanates [17]. Isothiocyanates have the ability to bind to sulfhydryl groups and cleave existing disulfide bonds on essential extracellular enzymes necessary for bacterial growth and 
UNDERGRADUATE RESEARCH IN NATURAL AND CLINICAL SCIENCE AND TECHNOLOGY (URNCST) JOURNAL Read more URNCST Journal articles and submit your own today at: https://www.urncst.com

survival. This effectively causes bacteriostatic and bactericidal effects $[15,17,28]$.

While much of the current research shows the effectiveness of phytochemicals in-vitro, there have been numerous studies showing their antibacterial activity in specific livestock and poultry. Studies on pigs infected with enterotoxigenic Escherichia coli demonstrated that those fed low doses of phytochemicals displayed decreased systemic and local inflammation compared to controls [13]. Similarly, concentrated flavonoid compounds from Psidium guajava have demonstrated antibacterial effects in chickens. Untreated controls had bacterial shedding counts of $86 \times 10^{9}$ $\mathrm{CFU} / \mathrm{mL}$ while chicks given $100 \mathrm{mg} / \mathrm{kg}$ of Psidium guayava had $43 \times 10^{9} \mathrm{CFU} / \mathrm{mL}$, a reduction of $50 \%$ [29]. Additionally, a meta-analysis conducted by Weber et al. (2012) indicated the ability of a phytochemical mixture of terpenes and alkaloids, in combination with benzoic acid, to improve growth and body weight in treated chickens by $25-85 \mathrm{~g}$ compared to controls [30]. Thus, phytochemicals can provide an alternative to combat the excessive usage of antibiotics at subtherapeutic doses for growth promotion [30].

\section{$\underline{\text { Antimicrobial peptides }}$}

AMPs are a naturally occurring group of small molecules produced by all organisms [31]. AMPs can be thought of as evolutionary ancient weapons that are used as the first line of defense to kill bacteria, yeasts, fungi, and even viruses [32-33]. In terms of the mechanism of action, most AMPs are cationic amphiphilic molecules. This allows for interaction and permeation with the negatively charged bacterial cell membranes as well as other large negatively charged molecules such as proteins. The resulting outcome is a change in cell morphology which blocks cell growth and eventually leads to death [34].

AMPs are a promising alternative to antibiotics, as they have been proven to promote animal productivity and growth. Specifically, studies have indicated their potential as an effective treatment for pigs undergoing post-weaning stress [35]. Currently, antibiotics are normally used to treat the symptoms of this stress which include intestinal issues such as weight loss and diarrhea, as well as immunological issues such as increased susceptibility to a pathogenic infection [35-36]. Microcin J25 (MccJ25) is an AMP that was isolated from a fecal strain of $E$. coli and has the potential to replace antibiotics [35]. Yu et al. (2017) demonstrated that weaning pigs given $\mathrm{MccJ} 25$ supplemented diets showed improved growth performance and reduced diarrhea. These positive effects were likely due to the improvement of the microbiota composition, and intestinal barrier function [36].

AMPs have also been shown as a promising alternative to antibiotics to help treat diseases. Clostridium perfringens has had a large negative impact on poultry production, as an overgrowth of this bacterium causes necrotic enteritis (NE). $\mathrm{NE}$ causes decreased weight gain and an increased mortality rate in poultry, costing the industry over two billion dollars annually [37-38]. Heo et al. (2018) discovered an AMP-producing strain, Streptococcus hyointestinalis B19 that showed an antimicrobial effect against $C$. perfringens [39]. S. hyointestinalis B19 produced a type of AMP known as a bacteriocin, which is a peptide that inhibits a large variety of microorganisms [40]. This bacteriocin-producing strain showcases one potential solution to control $C$. perfringens and help save the poultry industry billions of dollars [38].

\section{Probiotics}

Probiotics are living organisms (microorganisms or microbial mixtures), which are often referred to as "living drugs" administered to both humans and animals [41]. Probiotics are considered beneficial if they are: nonpathogenic, non-toxic, and can exert the desired effects when delivered in proper amounts [42]. Probiotics are often added to the diet, with the role of creating a beneficial microbial environment within the guts to help with growth promotion and disease prevention [43]. A particular subtype of probiotics is competitive exclusion products, which work by preventing the colonization of pathogenic bacteria. These products have shown high efficacy in disease prevention for young livestock [43-45].

One study examined whether probiotics have an effect on $C$. jejuni infections, one of the most common causes of food poisoning in broiler chickens [46-47]. At the 3 weeks mark, the prevalence of $C$. jejuni was $27 \%$ lower in the direct-fed microbial group compared to the control, although growth performance was the same among both groups [47]. Other studies have demonstrated that probiotic use could lead to $20 \%$ reduction in mortality in the experimental group compared to the control, a number that is comparable to antibiotic use [48]. Additionally, some studies have shown that probiotic use can increase productivity as measured by increased egg production in chickens [49]. Lastly, Torres-Rodriguez et al. (2007) concluded that Lactobacillus-based probiotic, FM-B11, resulted in a healthier turkey population and provided an economically favourable approach to poultry production due to reduced costs [50].

There has been an interest for probiotic use in ruminants. One review mentions how lactic acid bacteria (LAB) are essential for young calves, since they play a key role in reducing morbidity from diarrhea among calves [51]. One study looked at whether LABs have any effect on the uteruses of cattle, and concluded that specific strains of LAB can inhibit some aspects of metritis pathogenesis [52]. Similar studies have also been done on pigs. One study demonstrated that both Enterococcus faecium NCIMB 10415 and Bacillus cereus var. toyoi improved the gut health of piglets by reducing the incidence of post-weaning diarrhea by $59 \%, 45 \%, 39 \%$, and $44 \%$ across different trials, though only the latter significantly influenced piglets performance [53]. 
UNDERGRADUATE RESEARCH IN NATURAL AND CLINICAL SCIENCE AND TECHNOLOGY (URNCST) JOURNAL Read more URNCST Journal articles and submit your own today at: https://www.urncst.com

\section{Bacteriophages}

Bacteriophages (phages) are a class of viruses that utilize bacteria as a host. Phage therapy (PT) describes the usage of phages to kill pathogenic bacteria [54]. With regards to animal agriculture, PT has the potential to substitute antibiotics for the purposes of growth promotion, disease prevention (i.e. prophylaxis) in the animal, and prevention of zoonoses [7].

Phages have high specificity for targeted bacterial binding sites [55]. This is advantageous because beneficial microbiota will go unharmed, and the human ingestion of these phages is inconsequential [55]. However, a drawback of their high specificity is that a complement of phages must be implemented to target all pathogenic serovars of a given bacterium [55]. Sklar \& Joerger (2001) demonstrated this necessity in their analysis of PT for Salmonella enterica serovar enteritidis in chickens. While the administration of a single phage did not decrease bacterial counts in chickens, a combination of phages did by $0.3-1.3$ orders of magnitude [56]. Ideally, a phage or phage combination being used for PT will infect several serovars of a pathogenic bacterium. However, this would require multiple bacterial strains to share common surface receptors [57]. Indeed, phages specific to more than one bacterium exist in nature and have been identified. One study found two phages that target and lyse several pathogenic serovars of $E$. coli, while importantly leaving non-pathogenic strains unharmed [58].

Some phages are ineffective for PT. Firstly, temperate phages replicate without lysing the host bacterium, and are therefore incapable of rapidly infecting and killing large bacterial colonies [57,59-60]. Furthermore, genetic recombination may also occur between phage and bacterium, allowing for antibacterial resistance to be expressed in the bacterium, or alterations in the phage genome such that progeny phages carry and spread genes for antibacterial resistance or other harmful traits [55]. Virulent phages operating in the lytic cycle are therefore ideal candidates for PT as they immediately replicate and lyse their host, effectively decreasing the likelihood of genetic recombination events [55,59].

Disease prevention is an important application of PT in animal agriculture. PT may be most efficacious in poultry production, where the high population density of chickens leads to the rapid spread of phages [61]. Indeed, PT for prophylaxis in chickens to prevent colibacillosis has been demonstrated successfully [57]. In aquaculture, PT has also been shown to reduce incidences of vibriosis, a fatal disease caused by the bacterium Vibrio anguillarum. In one study, PT increased the survival rate of Atlantic salmon infected with $V$. anguillarum to $100 \%$ survival, compared to $10 \%$ survival with no PT [62].

Another application of PT is growth augmentation. This has been validated by Kim et al. (2014), who demonstrated enhanced growth in pigs with phage supplemented feed. This phage mixture targeted E. coli and Salmonella spp., among other pathogens, and resulted in improved average daily feed intake from 2079 to $2222 \mathrm{~g}$ [63].

Zoonoses are an important area of study for PT, as this research has the ability to prevent transmission of foodborne pathogens to humans. One study showed that a phage mixture ingested orally resulted in substantially reduced counts of a zoonotic pathogen, C. jejuni, in the guts of chickens [64].

\section{Discussion}

Phytochemicals, AMPs, probiotics, and bacteriophages all demonstrate potential to be feasible alternatives for antibiotics. While there may be limitations associated with their use, current data warrants further research for their broader implementation in agriculture.

Phytochemicals provide a promising alternative to antibiotics. However, since phytochemicals tend to have high MICs compared to other antibacterial alternatives, there are difficulties associated with their use as a monotherapy. Hence, interventions tend to require concentrated doses or be more combinative in nature using other adjunctives. There is a benefit to this, as phytochemicals allow increased activity and lower dosage of antibiotics, which decreases risk of developing resistant bacteria [14-15,65-66]. Future research could explore the concurrent effects of phytochemically treated animal products intended for human consumption [13]. With both the ability to promote growth as well as their bacteriostatic and bactericidal properties, there is value in continuing to study their use in livestock and poultry [13-15].

Although AMPs show great potential, they are not a perfect solution to the antibiotic resistance crisis as strategies are already being developed by organisms to combat AMPs. For example, gram-positive and gramnegative bacteria have evolved the ability to neutralize the net negative charge of their cell wall [37]. Without this negative charge, the cationic AMPs would have difficulty interacting and permeating the bacterial wall, thus preventing cell death. Another adaptation in bacteria is the thickening of their cell walls to prevent permeation. It is hypothesized that $E$. coli are able to upregulate glutamine synthetase, enhancing the production of the cell wall peptidoglycan layer, thus effectively thickening this layer and creating difficulties for proper AMP function [38-39].

Indeed, probiotics have displayed both growth promotion and disease prevention properties [43]. Probiotics could even have economic benefits for farmers, which further incentivizes their use as antibiotic alternatives [50]. Some interesting research has identified synergistic effects between AMPs and probiotics for the purpose of eliminating harmful bacteria. Many types of LAB have been shown to produce bacteriocins [67]. Umu et al (2016) investigated five bacteriocin producing probiotics, and showed that several of them were capable of inhibiting problematic families of gut bacteria (Staphylococcus, Enterococcaceae, and Clostridium) in mice [68]. Although 
UNDERGRADUATE RESEARCH IN NATURAL AND CLINICAL SCIENCE AND TECHNOLOGY (URNCST) JOURNAL Read more URNCST Journal articles and submit your own today at: https://www.urncst.com

further probiotic research must be conducted in an agricultural setting, current evidence showcases that using different alternatives synergistically can have a positive impact on aiding in the antibiotic resistance crisis.

PT has the capability to substitute many applications of antibiotic use in animal agriculture. One of the largest drawbacks of PT is its time sensitivity to the pathogen exposure, given that farmers need to be aware of a potential infection within days of its occurrence. One study demonstrated that a bacteriophage for $E$. coli treatment in poultry must be administered within 48 hours of the E. coli infection in order to significantly reduce mortality from colibacillosis [59]. Furthermore, phages with insufficient potency can allow for coexistence between phage and bacterium for a prolonged period of time, thus increasing the likelihood of phage resistant bacteria [69]. Future directions of PT include in-vivo trials to determine the efficacy of a variety of phage delivery methods.

Table 1: Summary of antibiotic alternatives

\begin{tabular}{|c|c|c|c|c|}
\hline Name & Mechanism of action & Current applications & Advantages & Disadvantages \\
\hline Phytochemicals & $\begin{array}{l}\text { Disruptive actions } \\
\text { towards bacterial } \\
\text { components and } \\
\text { immunomodulatory } \\
\text { effects }\end{array}$ & $\begin{array}{l}\text { Immunomodulatory } \\
\text { properties, growth } \\
\text { promotion, and disease } \\
\text { prevention in } \\
\text { agriculture practices } \\
\text { such as ruminants, } \\
\text { swine and poultry }\end{array}$ & $\begin{array}{l}\text { Can provide both } \\
\text { bacteriostatic and } \\
\text { bactericidal effects } \\
\text { through many } \\
\text { different mechanisms } \\
\text { and targeted structures }\end{array}$ & $\begin{array}{l}\text { High MIC requires } \\
\text { concentrated doses for } \\
\text { desired effects }\end{array}$ \\
\hline $\begin{array}{l}\text { Antimicrobial } \\
\text { peptides (AMPs) }\end{array}$ & $\begin{array}{l}\text { Interact and permeate } \\
\text { with negatively charged } \\
\text { bacterial cell } \\
\text { membranes as well as } \\
\text { other large negatively } \\
\text { charged molecules, } \\
\text { resulting in a change in } \\
\text { cell morphology, } \\
\text { blocking cell growth } \\
\text { and leading to death }\end{array}$ & $\begin{array}{l}\text { Growth promotion, } \\
\text { productivity promotion, } \\
\text { and treatment of } \\
\text { diseases in animals } \\
\text { such as swine and } \\
\text { poultry }\end{array}$ & $\begin{array}{l}\text { Can combine AMPs } \\
\text { and probiotics to } \\
\text { achieve a positive } \\
\text { synergistic effect } \\
\text { Broad- spectrum } \\
\text { activity } \\
\text { Provide bactericidal } \\
\text { effects }\end{array}$ & $\begin{array}{l}\text { Bacteria have evolved } \\
\text { thicker cell walls and } \\
\text { the ability to } \\
\text { neutralize the net } \\
\text { negative charge of } \\
\text { their cell wall, thus } \\
\text { stopping the } \\
\text { interaction and } \\
\text { permeation of the } \\
\text { bacterial wall }\end{array}$ \\
\hline Probiotics & $\begin{array}{l}\text { Prevents colonization } \\
\text { of pathogenic bacteria } \\
\text { and inflammation of the } \\
\text { gut }\end{array}$ & $\begin{array}{l}\text { Growth promotion and } \\
\text { disease preventions in } \\
\text { poultry and ruminants }\end{array}$ & $\begin{array}{l}\text { Beneficial for gut } \\
\text { microbiome } \\
\text { Economically } \\
\text { favourable compared } \\
\text { to traditional } \\
\text { antibiotics use }\end{array}$ & $\begin{array}{l}\text { Potential strain- } \\
\text { specific adverse } \\
\text { effects. }\end{array}$ \\
\hline $\begin{array}{l}\text { Bacteriophages } \\
\text { (phages) }\end{array}$ & $\begin{array}{l}\text { Targets and lyses } \\
\text { bacteria directly }\end{array}$ & $\begin{array}{l}\text { Growth promotion, } \\
\text { disease prevention, and } \\
\text { prevention of zoonotic } \\
\text { transmission in poultry } \\
\text { and livestock }\end{array}$ & $\begin{array}{l}\text { High specificity for } \\
\text { infected bacteria } \\
\text { (will not infect non- } \\
\text { pathogenic strains) }\end{array}$ & $\begin{array}{l}\text { Highly time sensitive } \\
\text { to the pathogen } \\
\text { exposure }\end{array}$ \\
\hline
\end{tabular}

\section{Conclusions}

Overall, this review explored various antibiotic alternatives and their use in animal agriculture. With the rise of antibiotic resistant bacteria, it has become evident that more diverse prophylactic alternatives are needed. The four alternatives covered in this review include: phytochemicals, antimicrobial peptides, probiotics, and bacteriophages. All of these interventions have demonstrated the capacity to either promote growth, prevent diseases, or potentially both. Interestingly, some of the alternatives, such as AMPs and probiotics, can have financial benefits. Moving forward, there is a vast potential for research as the diversity among these alternatives is tremendous. Indeed, with the rise in popularity, funding for research, and the shown efficacy of these interventions, there is hope for a future with the rational use of antibiotics. 
UNDERGRADUATE RESEARCH IN NATURAL AND CLINICAL SCIENCE AND TECHNOLOGY (URNCST) JOURNAL Read more URNCST Journal articles and submit your own today at: https://www.urncst.com

List of Abbreviations Used

AMP: antimicrobial peptide

phage: Bacteriophage

C. jejuni: Campylobacter jejuni

C. perfringens: Clostridium perfringens

E. coli: Escherichia coli

FDA: Food and Drug Administration

HGT: horizontal gene transfer

LAB: lactic acid bacteria

MccJ25: Microcin J25

MIC: minimal inhibitory concentration

NE: necrotic enteritis

PT: phage therapy

S. hyointestinalis: Streptococcus hyointestinalis

V. anguillarum: Vibrio anguillarum

\section{Conflicts of Interest}

The authors declare that they have no conflict of interests.

\section{Ethics Approval and/or Participant Consent}

This literature review did not require ethics approval and/or participant consent.

\section{Authors' Contributions}

All authors made substantial contributions to the conception and design of the work, conducted literature review, analysis and interpretation, drafted the manuscript, and gave final approval of the version to be published.

\section{Acknowledgements}

The authors do not wish to acknowledge any other parties.

\section{Funding}

This study was not funded.

\section{References}

[1] Van Boeckel TP, Brower C, Gilbert M, Grenfell BT, Levin SA, Robinson TP, et al. Global trends in antimicrobial use in food animals. Proceedings of the National Academy of Sciences of the United States of America. 2015 May;112(18):5649-54. https://doi.org/ 10.1073/pnas. 1503141112

[2] Manyi-Loh C, Mamphweli S, Meyer E, Okoh A. Antibiotic use in agriculture and its consequential resistance in environmental sources: Potential public health implications. Molecules. 2018;23(4). https://doi.org/10.3390/molecules23040795

[3] Chang Q, Wang W, Regev-Yochay G, Lipsitch M, Hanage WP. Antibiotics in agriculture and the risk to human health: How worried should we be? Evolutionary Applications. 2015 Mar;8(3):240-7. https://doi.org/ 10.1111/eva.12185

[4] Travers K, Barza M. Morbidity of Infections Caused by Antimicrobial- Resistant Bacteria. Clinical Infectious Diseases. 2002 Jun;34(s3):S131-4. https://doi.org/ $\underline{10.1086 / 340251}$

Karimi et al. | URNCST Journal (2020): Volume 4, Issue 7

DOI Link: https://doi.org/10.26685/urncst.194
[5] Ilić K, Jakovljević E, Škodrić-Trifunović V. Socialeconomic factors and irrational antibiotic use as reasons for antibiotic resistance of bacteria causing common childhood infections in primary healthcare. European Journal of Pediatrics. 2012 May;171(5):76777. http://doi.org/10.1007/s00431-011-1592-5

[6] Adjiri-Awere A, Van Lunen TA. Subtherapeutic use of antibiotics in pork production: Risks and alternatives. Canadian Journal of Animal Science. 2005;85(2):11730. https://doi.org/10.4141/A04-041

[7] Svircev A, Roach D, Castle A. Framing the Future with Bacteriophages in Agriculture. Viruses. 2018 25;10(5). https://doi.org/10.3390/v10050218

[8] Robinson TP, Bu DP, Carrique-Mas J, Fèvre EM, Gilbert M, Grace D, et al. Antibiotic resistance is the quintessential One Health issue. Trans R Soc Trop Med Hyg. 2016 Jul;110(7):377-80. https://doi.org/10.1093/ trstmh/trw048

[9] Read AF, Woods RJ. Antibiotic resistance management. Evolution, Medicine, and Public Health. 2014 Oct;2014(1):147-147. https://doi.org/10.1093/emph/ eou024

[10] Von Wintersdorff CJH, Penders J, Van Niekerk JM, Mills ND, Majumder S, Van Alphen LB, et al. Dissemination of antimicrobial resistance in microbial ecosystems through horizontal gene transfer. Frontiers in Microbiology. 2016 Feb;7:173-173. https://doi.org/ 10.3389/fmicb.2016.00173

[11] Norman A, Hansen LH, Sørensen SJ. Conjugative plasmids: Vessels of the communal gene pool. Philosophical Transactions of the Royal Society B: Biological Sciences. 2009 Aug;364(1527):2275-89. https://doi.org/10.1098/rstb.2009.0037

[12] Jutkina J, Marathe NP, Flach CF, Larsson DGJ Antibiotics and common antibacterial biocides stimulate horizontal transfer of resistance at low concentrations. Science of the Total Environment. 2018 Mar;616617:172-8. $\quad$ https://doi.org/10.1016/j.scitotenv.2017.10 .312

[13] Lillehoj H, Liu Y, Calsamiglia S, Fernandez-Miyakawa ME, Chi F, Cravens RL, et al. Phytochemicals as antibiotic alternatives to promote growth and enhance host health. Vet Res. 2018 31;49(1):76. https://doi.org/10 .1186/s13567-018-0562-6

[14] Bayir AG, Kiziltan HS, Kocyigit A. Chapter 1 - Plant Family, Carvacrol, and Putative Protection in Gastric Cancer. In: Watson RR, Preedy VR, editors. Dietary Interventions in Gastrointestinal Diseases. Academic Press; 2019 p. 3-18. https://doi.org/10.1016/B978-012-814468-8.00001-6

[15] Barbieri R, Coppo E, Marchese A, Daglia M, SobarzoSánchez E, Nabavi SF, et al. Phytochemicals for human disease: An update on plant-derived compounds antibacterial activity. Microbiol Res. 2017 Mar;196:4468. https://doi.org/10.1016/j.micres.2016.12.003 
UNDERGRADUATE RESEARCH IN NATURAL AND CLINICAL SCIENCE AND TECHNOLOGY (URNCST) JOURNAL

Read more URNCST Journal articles and submit your own today at: https://www.urncst.com

[16] Simões M, Bennett RN, Rosa EAS. Understanding antimicrobial activities of phytochemicals against multidrug resistant bacteria and biofilms. Nat Prod Rep. 2009 Jun;26(6):746-57. https://doi.org/10.1039/ b821648g

[17]Borges A, Saavedra MJ, Simões M. Insights on antimicrobial resistance, biofilms and the use of phytochemicals as new antimicrobial agents. Curr Med Chem. 2015;22(21):2590-614. https://doi.org/10.2174/ 0929867322666150530210522

[18] Horváth G, Molnár P, Radó-Turcsi E, Deli J, Kawase M, Satoh K, et al. Carotenoid composition and in vitro pharmacological activity of rose hips. Acta Biochim Pol. 2012;59(1):129-32. https://doi.org/10.18388/ abp.2012_2187

[19] Bhagavathy S, Sumathi P, Jancy Sherene Bell I. Green algae Chlorococcum humicola-a new source of bioactive compounds with antimicrobial activity. Asian Pacific Journal of Tropical Biomedicine. 2011 Sep 1;1(1, Supplement):S1-7. https://doi.org/10.1016/ $\underline{\text { S2221-1691(11)60111-1 }}$

[20] Milani A, Basirnejad M, Shahbazi S, Bolhassani A. Carotenoids: biochemistry, pharmacology and treatment. Br J Pharmacol. 2017;174(11):1290-324. https://doi.org/10.1111/bph.13625

[21] De R, Kundu P, Swarnakar S, Ramamurthy T, Chowdhury A, Nair GB, et al. Antimicrobial activity of curcumin against Helicobacter pylori isolates from India and during infections in mice. Antimicrob Agents Chemother. 2009 Apr;53(4):1592-7. https://doi.org/ 10.1128/aac.01242-08

[22] Nabi F, Arain MA, Rajput N, Alagawany M, Soomro J, Umer $\mathrm{M}$, et al. Health benefits of carotenoids and potential application in poultry industry: A review. J Anim Physiol Anim Nutr (Berl). 2020 Apr 25; https://doi.org/10.1111/jpn.13375

[23] Santos R, Pimenta G, Dias-Souza M. Carotenoids and flavonoids can impair the effectiveness of some antimicrobial drugs against clinical isolates of Escherichia coli and Staphylococcus aureus. International Food Research Journal. 2015 Apr 23;22:1777-82.

[24]Davidson PM, Taylor TM. Chemical Preservatives and Natural Antimicrobial Compounds. Food Microbiology: Fundamentals and Frontiers, Third Edition. 2007 Jan 1;713-45. http://dx.doi.org/10.1128/ 9781555815912.ch33

[25]Arsi K, Donoghue AM, Venkitanarayanan K, Kollanoor- Johny A, Fanatico AC, Blore PJ, et al. The Efficacy of the Natural Plant Extracts, Thymol and Carvacrol against Campylobacter Colonization in Broiler Chickens. Journal of Food Safety. 2014;34(4):321-5. https://doi.org/10.1111/jfs.12129

[26]Burt SA, Fledderman MJ, Haagsman HP, van Knapen F, Veldhuizen EJA. Inhibition of Salmonella enterica serotype Enteritidis on agar and raw chicken by carvacrol vapour. Int J Food Microbiol. 2007 Nov 1;119(3):346-50.

https://doi.org/10.1016/j.ijfoodmicro.2007.05.002

[27] Burt S. Essential oils: their antibacterial properties and potential applications in foods--a review. Int $\mathbf{J}$ Food Microbiol. 2004 Aug 1;94(3):223-53. https://doi.org/ 10.1016/j.ijfoodmicro.2004.03.022

[28] Aziz M, Karboune S. Natural antimicrobial/antioxidant agents in meat and poultry products as well as fruits and vegetables: A review. Crit Rev Food Sci Nutr. 2018 Feb 11;58(3):486-511. https://doi.org/10.1080/ $\underline{10408398.2016 .1194256}$

[29] Geidam YA, Ambali AG, Onyeyili PA, Tijjani MB, Gambo HI, Gulani IA. Antibacterial efficacy of ethyl acetate fraction of Psidium guajava leaf aqueous extract on experimental Escherichia coli (O78) infection in chickens. Vet World. 2015 Mar;8(3):358-62. https://dx.doi.org/10.14202\%2Fvetworld.2015.358-362

[30] Weber GM, Michalczuk M, Huyghebaert G, Juin H, Kwakernaak C, Gracia MI. Effects of a blend of essential oil compounds and benzoic acid on performance of broiler chickens as revealed by a metaanalysis of 4 growth trials in various locations. Poult Sci. 2012 Nov;91(11):2820-8. https://doi.org/10.3382/ ps.2012-02243

[31] Wang S, Zeng X, Yang Q, Qiao S. Antimicrobial peptides as potential alternatives to antibiotics in food animal industry. International Journal of Molecular Sciences. 2016 May;17(5). https://doi.org/10.3390/ ijms 17050603

[32]Zasloff M. Antimicrobial peptides of multicellular organisms. Nature. 2002 Jan;415(6870):389-95. https://doi.org/10.1038/415389a

[33] Zhang LJ, Gallo RL. Antimicrobial peptides. Current Biology. 2016 Jan;26(1):R14-9. https://doi.org/10.1016/ j.cub.2015.11.017

[34]Lei J, Sun LC, Huang S, Zhu C, Li P, He J, et al. The antimicrobial peptides and their potential clinical applications. American Journal of Translational Research. 2019;11(7):3919-31.

[35] Campbell JM, Crenshaw JD, Polo J. The biological stress of early weaned piglets. Journal of Animal Science and Biotechnology. 2013 Mar;4(1):19-19. https://doi.org/10.1186/2049-1891-4-19

[36] Yu HT, Ding XL, Li N, Zhang XY, Zeng XF, Wang S, et al. Dietary supplemented antimicrobial peptide microcin J25 improves the growth performance, apparent total tract digestibility, fecal microbiota, and intestinal barrier function of weaned pigs1,2. Journal of Animal Science. 2017 Nov;95(11):5064-76. https://doi.org/10.2527/jas2017.1494

[37] Timbermont L, Haesebrouck F, Ducatelle R, Van Immerseel F. Necrotic enteritis in broilers: an updated review on the pathogenesis. Avian Pathology. 2011 Aug;40(4):341-7. https://doi.org/10.1080/03079457 $\underline{.2011 .590967}$ 
UNDERGRADUATE RESEARCH IN NATURAL AND CLINICAL SCIENCE AND TECHNOLOGY (URNCST) JOURNAL

Read more URNCST Journal articles and submit your own today at: https://www.urncst.com

[38] Van der Sluis W. Clostridial enteritis is an often underestimated problem. World poultry. 2000;16(7): 42-3.

[39] Heo S, Kim MG, Kwon M, Lee HS, Kim GB. Inhibition of Clostridium perfringens using bacteriophages and bacteriocin producing strains. Korean Journal for Food Science of Animal Resources. 2018 Feb;38(1):88-98. https://doi.org/10.5851/kosfa 2018.38.1.88

[40] Lopetuso LR, Giorgio ME, Saviano A, Scaldaferri F, Gasbarrini A, Cammarota G. Bacteriocins and bacteriophages: Therapeutic weapons for gastrointestinal diseases? International Journal of Molecular Sciences. 2019 Jan;20(1). https://doi.org/ 10.3390/ijms20010183

[41] Elmer GW. Probiotics: "living drugs.” Am J Health Syst Pharm. 2001 Jun 15;58(12):1101-9. https://doi.org/ 10.1093/ajhp/58.12.1101

[42] Hill C, Guarner F, Reid G, Gibson GR, Merenstein DJ, Pot B, et al. Expert consensus document. The International Scientific Association for Probiotics and Prebiotics consensus statement on the scope and appropriate use of the term probiotic. Nat Rev Gastroenterol Hepatol. 2014 Aug;11(8):506-14. https://doi.org/10.1038/nrgastro.2014.66

[43] Chaucheyras-Durand F, Durand H. Probiotics in animal nutrition and health. Benef Microbes. 2010 Mar;1(1):3-9. https://doi.org/10.3920/BM2008.1002

[44] Callaway TR, Edrington TS, Anderson RC, Harvey RB, Genovese KJ, Kennedy CN, et al. Probiotics, prebiotics and competitive exclusion for prophylaxis against bacterial disease. Anim Health Res Rev. 2008 Dec;9(2):217-25. https://doi.org/10.1017/S146625230 $\underline{8001540}$

[45] Oliver SP, Patel DA, Callaway TR, Torrence ME. ASAS Centennial Paper: Developments and future outlook for preharvest food safety. J Anim Sci. 2009 Jan;87(1):419-37. https://doi.org/10.2527/jas.20082008-1151

[46] Willis WL, Reid L. Investigating the effects of dietary probiotic feeding regimens on broiler chicken production and Campylobacter jejuni presence. Poult Sci. 2008 Apr;87(4):606-11. https://doi.org/10.3382/ ps.2006-00458

[47] Young KT, Davis LM, Dirita VJ. Campylobacter jejuni: molecular biology and pathogenesis. Nat Rev Microbiol. 2007 Sep;5(9):665-79. https://doi.org/ 10.1038/nrmicro1718

[48] Dersjant-Li Y, Awati A, Kromm C, Evans C. A direct fed microbial containing a combination of three-strain Bacillus sp. can be used as an alternative to feed antibiotic growth promoters in broiler production. Journal of Applied Animal Nutrition. 2013 ed;2. https://doi.org/10.1017/jan.2014.4

[49] Kurtoglu V, Kurtoglu F, Seker E, Coskun B, Balevi T, Polat ES. Effect of probiotic supplementation on laying hen diets on yield performance and serum and egg yolk cholesterol. Food Addit Contam. 2004 Sep;21(9):81723. https://doi.org/10.1080/02652030310001639530

[50] Torres-Rodriguez A, Donoghue AM, Donoghue DJ, Barton JT, Tellez G, Hargis BM. Performance and condemnation rate analysis of commercial turkey flocks treated with a Lactobacillus spp.-based probiotic. Poult Sci. 2007 Mar;86(3):444-6. https://doi.org/10.1093/ps/86.3.444

[51] Uyeno Y, Shigemori S, Shimosato T. Effect of Probiotics/Prebiotics on Cattle Health and Productivity. Microbes Environ. 2015 Jun;30(2):126-32. https://doi.org/10.1264/jsme2.ME14176

[52] Otero MC, Morelli L, Nader-Macías ME. Probiotic properties of vaginal lactic acid bacteria to prevent metritis in cattle. Lett Appl Microbiol. 2006 Jul;43(1):91-7. https://doi.org/10.1111/j.1472-765X $.2006 .01914 . \mathrm{x}$

[53] Taras D, Vahjen W, Simon O. Probiotics in pigs modulation of their intestinal distribution and of their impact on health and performance. Livestock Science. 2007 May 1;108(1):229-31. https://doi.org/10.1016/ j.livsci.2007.01.075

[54] Wittebole X, De Roock S, Opal SM. A historical overview of bacteriophage therapy as an alternative to antibiotics for the treatment of bacterial pathogens. Virulence. 2014 Jan 1;5(1):226-35. https://doi.org/ 10.4161/viru. 25991

[55] Joerger RD. Alternatives to antibiotics: bacteriocins, antimicrobial peptides and bacteriophages. Poult Sci. 2003 Apr;82(4):640-7. $\quad$ https://doi.org/10.1093/ps/ $\underline{82.4 .640}$

[56] Sklar IB, Joerger RD. Attempts to Utilize Bacteriophage to Combat Salmonella Enterica Serovar Entemtidis Infection in Chickens. Journal of Food Safety. 2001;21(1):15-29. https://doi.org/10.1111/j .1745-4565.2001.tb00305.x

[57] Johnson RP, Gyles CL, Huff WE, Ojha S, Huff GR, Rath NC, et al. Bacteriophages for prophylaxis and therapy in cattle, poultry and pigs. Anim Health Res Rev. 2008 Dec;9(2):201-15. https://doi.org/10.1017/ S1466252308001576

[58] Viscardi M, Perugini AG, Auriemma C, Capuano F, Morabito S, Kim K-P, et al. Isolation and characterisation of two novel coliphages with high potential to control antibiotic-resistant pathogenic Escherichia coli (EHEC and EPEC). Int J Antimicrob Agents. 2008 Feb;31(2):152-7.

[59] Huff WE, Huff GR, Rath NC, Balog JM, Donoghue AM. Alternatives to antibiotics: utilization of bacteriophage to treat colibacillosis and prevent foodborne pathogens. Poult Sci. 2005 Apr;84(4):655-9. https://doi.org/10.1093/ps/84.4.655

[60] Loc-Carrillo C, Abedon ST. Pros and cons of phage therapy. Bacteriophage. 2011;1(2):111-4. https://doi.org/ $\underline{10.4161 / \text { bact.1.2.14590 }}$ 
UNDERGRADUATE RESEARCH IN NATURAL AND CLINICAL SCIENCE AND TECHNOLOGY (URNCST) JOURNAL

Read more URNCST Journal articles and submit your own today at: https://www.urncst.com

[61] Atterbury RJ. Bacteriophage biocontrol in animals and meat products. Microb Biotechnol. 2009 Nov;2(6):60112. https://doi.org/10.1111/j.1751-7915.2009.00089.x

[62] Higuera G, Bastías R, Tsertsvadze G, Romero J, Espejo RT. Recently discovered Vibrio anguillarum phages can protect against experimentally induced vibriosis in Atlantic salmon, Salmo salar. Aquaculture. 2013 May 10;392-395:128-33. http://dx.doi.org/10 $.1016 /$ j.aquaculture.2013.02.013

[63] Kim KH, Ingale SL, Kim JS, Lee SH, Lee JH, Kwon IK, et al. Bacteriophage and probiotics both enhance the performance of growing pigs but bacteriophage are more effective. Animal Feed Science and Technology. 2014 Oct 1;196:88-95. https://doi.org/10.1016/ j.anifeedsci.2014.06.012

[64] Loc Carrillo C, Atterbury RJ, el-Shibiny A, Connerton PL, Dillon E, Scott A, et al. Bacteriophage therapy to reduce Campylobacter jejuni colonization of broiler chickens. Appl Environ Microbiol. 2005 Nov;71(11): 6554-63. https://doi.org/10.1128/AEM.71.11.65546563.2005

[65] Santiago C, Pang EL, Lim K-H, Loh H-S, Ting KN. Inhibition of penicillin-binding protein 2a (PBP2a) in methicillin resistant Staphylococcus aureus (MRSA) by combination of ampicillin and a bioactive fraction from Duabanga grandiflora. BMC Complement Altern Med. 2015 Jun 10;15:178. https://doi.org/ $\underline{10.1186 / s 12906-015-0699-Z}$

[66] Nascimento GGF, Locatelli J, Freitas PC, Silva GL. Antibacterial activity of plant extracts and phytochemicals on antibiotic-resistant bacteria. Brazilian Journal of Microbiology. 2000 Oct;31(4):247-56. https://doi.org/10.1590/S1517$\underline{83822000000400003}$

[67] Dobson A, Cotter PD, Ross RP, Hill C. Bacteriocin production: a probiotic trait? Appl Environ Microbiol. 2012 Jan;78(1):1-6. https://doi.org/10.1128/aem.0557611

[68] Umu ÖCO, Bäuerl C, Oostindjer M, Pope PB, Hernández PE, Pérez-Martínez G, et al. The Potential of Class II Bacteriocins to Modify Gut Microbiota to Improve Host Health. PLoS ONE. 2016;11(10):e0164036. https://doi.org/10.1371/journal pone.0164036

[69] Mizoguchi K, Morita M, Fischer CR, Yoichi M, Tanji Y, Unno H. Coevolution of bacteriophage PP01 and Escherichia coli $\mathrm{O} 157: \mathrm{H} 7$ in continuous culture. Appl Environ Microbiol. $2003 \quad$ Jan;69(1):170-6. https://doi.org/10.1128/AEM.69.1.170-176.2003

\section{Article Information}

Managing Editor: Jeremy Y. Ng

Peer Reviewers: Janice Tai, Sonya Kouthouridis

Article Dates: Received May 29 20; Accepted Jul 24 20; Published Aug 2820

\section{Citation}

Please cite this article as follows:

Karimi A, Shulman C, Tchoudnovski D, Tobis M. An agricultural perspective for combating antibiotic resistance: A literature review. URNCST Journal. 2020 Aug 28: 4(7). https://urncst.com/index.php/urncst/article/view/194 DOI Link: https://doi.org/10.26685/urncst.194

\section{Copyright}

(C) Arian Karimi, Cole Shulman, Dennis Tchoudnovski, Matthew Tobis. (2020). Published first in the Undergraduate Research in Natural and Clinical Science and Technology (URNCST) Journal. This is an open access article distributed under the terms of the Creative Commons Attribution License (https://creativecommons.org/licenses/by/4.0/), which permits unrestricted use, distribution, and reproduction in any medium, provided the original work, first published in the Undergraduate Research in Natural and Clinical Science and Technology (URNCST) Journal, is properly cited. The complete bibliographic information, a link to the original publication on http://www.urncst.com, as well as this copyright and license information must be included. 
UNDERGRADUATE RESEARCH IN NATURAL AND CLINICAL SCIENCE AND TECHNOLOGY (URNCST) JOURNAL

Read more URNCST Journal articles and submit your own today at: https://www.urncst.com

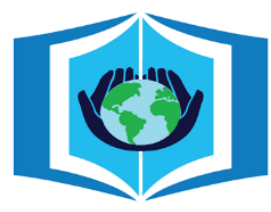

\section{URNCST Journal \\ "Research in Earnest"}

\section{Funded by the Government of Canada}

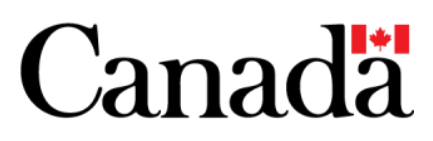

Do you research in earnest? Submit your next undergraduate research article to the URNCST Journal!

| Open Access | Peer-Reviewed | Rapid Turnaround Time | International | | Broad and Multidisciplinary | Indexed | Innovative | Social Media Promoted |

Pre-submission inquiries? Send us an email at info@ urncst.com | Facebook, Twitter and LinkedIn: @ URNCST

Submit YOUR manuscript today at https://www.urncst.com! 